\title{
Multi-actor networks and innovation niches: University training for local agroecological dynamization
}

Authors: Daniel López-García, Laura Calvet-Mir, Marina Di Masso, Josep Espluga.

\section{$\underline{\text { Abstract }}$}

The global environmental and social-economic crises of industrialized agriculture have led to the emergence of agroecology as an alternative approach aiming to increase the ecological, social and economic sustainability of agri-food systems. The 'multi-level perspective' is now a widely used framework to understand and promote the upscaling of local innovation niches, such as agroecology, to broader scales (e.g. regional, national, international), thus reconfiguring the dominant socio-technical regimes. Additionally, emergent 'hybrid forums' can provide a space between niche and regime where niche innovators can become important actors in scaling up and out emergent innovations. In this paper, we examine a university training program (postgraduate diploma in Local Agroecological Dynamization at the Universitat Autònoma de Barcelona), to better understand its role as a 'hybrid forum'. Our analysis focuses especially on how the program, as an example of a hybrid forum, worked to reconfigure practices, concepts, and tools of local development practitioners. We also assess to what extent the program contributed to transitioning local development institutions toward agroecology. An online survey $(n=46)$ and in-depth interviews $(n=16)$ were carried out to determine how the training program has impacted the student's opinions and their respective institutions. The results show that most of the students consider that they have acquired new theoretical frameworks and useful methods to re-framing their local development projects, that new alliances with multi-actor networks have been perceived, and that some internal changes of the local development have taken place. We conclude that the training program, as a hybrid forum, is capable of upscaling niche innovations through linkages with different kind of actors both from the niche and the regime. Political changes in the socio-technical landscape level offer an opportunity to amplify the impact of the innovations which are being generated by those multi-actor networks, but with a limited multi-level impact as far as institutional regime-actors not aligned with agroecological transition keep the most of the competencies on agri-food systems. 
Keywords: agroecology, agroecological transitions, hybrid actors, hybrid forums, multi-level perspective, grassroots innovation and social innovation.

\author{
Abbreviations: \\ LAeD: Local Agroecological Dynamization \\ MLP: Multi-Level Perspective \\ NGO: Non-Governmental Organization
}

\title{
Contact information:
}

Daniel López-García (corresponding autor): daniel@entretantos.org, Fundación Entretantos, c/ Arzobispo José Delicado 1, Valladolid, 47014, España.

Laura Calvet-Mir: lcalvetmir@gmail.com, Internet Interdisciplinary Institute (IN3), Universitat Oberta de Catalunya, Barcelona and Institut de Ciència $i$ Tecnologia Ambientals Universitat Autònoma de Barcelona, carrer de les Columnes s/n, 08193 Bellaterra, Barcelona.

Marina Di Masso: madimasso@gmail.com, Agroecology and Alternative Food Systems Chair, Universitat de Vic-Universitat Central de Catalunya, Carrer de la Sagrada Família, 7, Vic, 08500 Catalunya, España.

Josep Espluga: joseplluis.espluga@uab.cat, Institut de Govern i Polítiques Públiques, Universitat Autònoma de Barcelona. Edifici B, Facultat de CCPP i Sociologia. Campus de la UAB, 08193 Bellaterra, Catalunya, España.

\section{Author biographies:}

Daniel López-García (Ph.D. in Agroecology) is a researcher at Fundación Entretantos, coordinator of the Post-graduate Program 'Local Agroecological Dynamization' of the Universitat Autònoma de Barcelona, and lecturer at three master programs on Agroecology and Organic Farming. His major research field is agroecological transitions, focusing on alternative food networks, localized food systems, agroecologyoriented food policies and food governance. He has combined mixed research approaches combining participatory, qualitative and quantitative social research. Recent research focuses on participatory methodologies for urban and city-region food policy planning.

Laura Calvet-Mir (Ph.D. in Environmental Science) is a research fellow at IN3-UOC (Barcelona, Spain) and affiliated researcher at ICTA-UAB (Barcelona, Spain). Her research focuses on urban and rural agriculture, agroecological transitions and biocultural diversity. In studying local social-ecological systems, Dr. Calvet-Mir has combined ethnographic approaches with quantitative methods such as statistics and social network analyses. Her main research interests are agrobiodiversity, agroecology, ecosystem services, ethnoecology, political ecology, social network analysis, and traditional ecological knowledge.

Marina Di Masso Tarditti (Ph.D. in Sociology) is a Juan de la Cierva research fellow at the Agroecology and Alternative Food Systems Chair of the UVic-UCC, Spain. Her major research interests are transformative processes of social change. Particularly her research focuses on critical perspectives of the global agrifood system, alternative food networks, and food sovereignty as a transformative paradigm. Recent research and personal interests include wider alternative socioeconomic practices, with a focus on 
feminist economics and social and solidarity-based economy. She is a member of the Inclusive Societies, Policies and Communities at Uvic-UCC.

Josep Espluga is a sociologist, associate professor at the Departament of Sociology at the Universitat Autònoma de Barcelona (UAB) (Spain), and researcher at the Institute of Government and Public Policies (IGOP). He is also member of the Research group for Agriculture, Livestock and Food under Globalisation (ARAG-UAB). His major research field is environmental and health sociology, with special focus on the social perception of risk. $\mathrm{He}$ is co-director of the Post-graduate Program 'Local Agroecological Dynamization', and coordinates the Minor on Sustainable Development and Global Citizenship of the UAB.

\section{$\underline{\text { Acknowledgements }}$}

We would like to thank Ariadna Pomar-León and Guillem Tendero-Acín, as cocoordinators of the Training Program of Local Agroecological Dynamization, for their unvaluable cooperation for the present paper and in the training program itself. We would also like to thank all intervewees and respondants of the survey for their cooperation with the present research and their daily effort for agroecological transitions in Catalonia and Spain. Lastly, we would like to thank the special issue editors and the anonimous reviewers for their patient and invaluable comments, which really strengthened and enriched the paper.

\section{Paper text:}

\section{Introduction}

Local Agroecological Dynamization to promote agroecological transitions

The worldwide environmental and social-economic crisis of industrialized agriculture has led to the emergence of agroecology as an alternative approach aiming to increase agri-food systems' sustainability from an ecological, social and economic perspective (Francis et al. 2003). Agroecology was early defined as a theoretical and methodological framework to apply ecological concepts and principles to the design of sustainable agricultural systems (Altieri 1983; Gliessman 2002). Later developments addressed the need to also integrate the cultural, economic and social features of agroecosystems, as farming sustainability challenges are deeply conditioned by other non-ecological processes (Guzmán et al. 2000). According to Méndez et al. (2016), there still are two predominant perspectives on agroecology: one focused on agronomic and ecological processes related to farming systems, and another focused on wider agrifood system issues which engage natural sciences with social sciences. In this paper, we follow the second perspective as it takes into account the different features affecting agri-food systems (i.e., ecological, socio-cultural and political), and thus addresses a more comprehensive approach to its sustainability.

As an action-oriented approach, agroecology seeks scaling-out agri-food systems' sustainability in a process called 'agroecological transition' (Méndez et al. 2016). Several Spanish case studies stress that challenges for agroecological transition are often not only ecological but related to socio-cultural and political dimensions of agroecology (Guzmán et al. 2016). Indeed, the transition from industrialized to 
agroecological systems is not smooth (Lobley et al. 2009; Milestad et al. 2010). It requires specific extension practices adapted to entirely different systems of agricultural management, which also needs a collective process of individual and social learning (Röling and Wagemakers 1998; Cúellar and Calle-Collado 2011). Thus, the classical innovations adoption model used for agricultural modernization (Rogers 1962) is not readily adapted to agroecology (Padel 2001, 2008; Heleba et al. 2016). A more complex approach is required which articulates the ecological-productive dimension of agroecology (farm scale) with other dimensions corresponding to higher scales (i.e., rural development and socio-political dimensions) (Guzmán et al. 2016).

Local Agroecological Dynamization (LAeD) is a strategy for promoting local sovereignty through a set of methods and tools that address the resilience and empowerment of local communities, and incorporates a participative and territorial approach. The LAeD was proposed in the second decade of the 2000s as a practical tool to promote agri-food systems' sustainability at a local scale through agroecological transition processes (see López-García and Guzmán 2014; López-García et al. 2015 for an in-depth knowledge of its origins). LAeD mobilizes local communities' actornetworks, resources, and capabilities through the reactivation of local agricultural production. LAeD also promotes leadership amongst farmers, multi-actor networking, agroecological education, traditional agroecological knowledge, conservation and alternative food networks. For this purpose, it articulates participatory action-research methodologies with other research and community development methods to enhance local communities' capabilities to build up appropriate, comprehensive, inclusive and territory-based agroecological projects.

\section{Agroecological Transitions from a Multi-Level Perspective}

Within a holistic approach, agroecological transitions might be understood as comprehensive processes of agri-food system socio-technical transition. Thus, as a radical (but progressive) shift from one socio-technical regime to another, involving a change in the technology, infrastructures, cultures, rules, values, institutions and practices of a societal system (Geels 2002, 2010; Darnhofer 2015). In recent years, a growing amount of literature on agri-food transitions to sustainability was produced following the Multi-Level Perspective (MLP). MLP has been noted as an appropriate strategy to understand and promote the upscaling of local agroecological transition processes to regional or higher administration levels (Levidow et al. 2014). Such an approach covers two main gaps on agroecological transitions research (Sanderson and Ioris 2017): (1) an excessive focus on the farm level, in which agroecological transition is sometimes confused with conversion to organic farming, and regime-niche interactions are not explicitly addressed (see Guzmán et al. 2000; Gliessman and Rosenmeyer 2010; Guzmán et al. 2013). (2) the development of methodological tools without a robust theoretical framework on socio-technical transitions (see Wezel et al. 2015; Duru et al. 2015; Méndez et al. 2016).

From the MLP perspective, transitions to sustainability are 'non-linear processes that result from the interplay of developments at three analytical levels: niches (the locus for radical innovations), socio-technical regimes (the locus of established practices and associated rules that stabilize existing systems), and exogenous (socio-technical) landscapes' (Geels 2010:26). Within agroecology, niches are social spaces where multiactor alliances (e.g., farmers, consumers, NGOs and potentially extension or research services) protect farming innovations linked to alternative food networks and new 
institutions for agri-agri-food system sustainability (Levidow et al. 2014; Méndez et al. 2016). The ability of such networks to address the social, cultural, economic and ecological challenges of agri-food systems within a comprehensive framework is what creates the transformative character of innovations. It thus leads to stable regime reconfigurations (Levidow et al. 2014) accomplished through a progressive, diverse and complex process of niche-regime interactions which include practices and actors (Geels 2010, 2011; Darnhofer 2015).

Regimes are neither monolithic nor free of internal conflicts, but they change following a co-evolutionary pattern in interaction with niches and socio-technical landscapes (Geels 2011; Díaz et al. 2013; Darnhofer 2015). Within time, regimes can show performance weaknesses which introduce pressure for innovation. Once a window of opportunity appears out of regime malfunctioning, innovation niches emerge which can lead to regime reconfigurations (Elzen et al. 2011; Díaz et al. 2013). Each of these above mentioned analytical levels should be aligned to allow niche-innovations to break-through into regime reconfiguration (Darnhofer 2015). However, the interrelations between niche and regimes which lead to effective, radical transitions are still under discussion. Elzen et al. (2012) distinguish the process of 'anchoring' when a novelty spreads and becomes an innovation niche and 'linking' when a niche establishes durable links with a regime. They propose three types of anchoring: (1) technological, when a technological novelty is introduced in a productive sector or territory; (2) network, when the novelty spreads over additional territories or sectors through actors' intensified contact and knowledge exchange; and (3) institutional, when the diffusion of the novelty is adopted by institutions and somehow supported by public policies, even if only in a marginal way. Bui et al. (2016) establish three stages for regime reconfiguration: (1) the emergence of alternative initiatives; (2) the construction of a socio-technical niche through the enrollment of new actors; and (3) the construction of an alternative model, which impacts public bodies and generates related public policies.

An overall consensus can be observed regarding the collaborative nature of innovation processes on agri-food sustainability transitions and on the central role of multi-actor networks beyond the role of individuals (Ploeg and Marsden 2008; Lamine 2011; Neumeier 2012; Bui et al. 2016). Multi-actor networks' role in transitioning to sustainability is twofold: (1) as an operational core element on the maturation of novelties ('network anchoring') and the upscaling of niches into regime reconfiguration (Tisenkopfs et al. 2009; Elzen et al. 2012; Bui et al. 2016), and (2) as a conduit to strengthen the transformative elements of innovations and to create a protective environment for niche-actors to face regime-actors' pressures against regime reconfiguration (Díaz et al. 2013; Levidow et al. 2014; Darnhofer 2015). The 'innovation broker' profile would respond, therefore, to capabilities and skills oriented to the activation and reconfiguration of such networks and the associated cooperative processes (Galli and Brunori 2011). Such profiles could benefit by being 'hybrid actors', as their primary function is the creation of new alliances (Roep and Wiskerke 2004; Elzen et al. 2012; Díaz et al. 2013). Hybrid actors show characteristics of belonging to the regime as well as to the niche (Elzen et al. 2012). The challenge of niche-actors is thus identifying the hybrid actors and enrolling them in the sociotechnical transition (Díaz et al. 2013) through the creation of a hybrid forum (Elzen et al. 2012). A hybrid forum is an area where niche and regime overlap, characterized by relatively stabilized innovation networks (resulting from network anchoring) where regime and niche developments come together at the most concrete level. 
Our objective in this paper is to examine a university training program (postgraduate diploma in Local Agroecological Dynamization at the Universitat Autònoma de Barcelona), to better understand its role as a 'hybrid forum' which acts as a tool for promoting agroecological transitions, to accomplish the following: (i) reconfigure the hegemonic socio-technical regime; (ii) contribute to the reconfiguration of regime practices; (iii) expand agroecological concepts and tools for local development practitioners; and (iv) lead local development institutions towards an agroecological transition. In the following section, we will introduce the assessed agroecological university training, its aims and primary challenges. Section three briefly describes the case study and explains the methods used to obtain the results exposed in section four, while section five discusses these results within the framework of MLP. Finally, we conclude by tackling the impact of the university post-graduate training program in agroecological transitions, and discussing new insights on the application of the MLP to agroecological transitions framework.

\section{Training for agroecological transitions through multi-actor networks}

According to several authors (e.g., Guzmán et al. 2016, Padel 2001, 2008; Wheeler 2008), agroecological transitions need new approaches beyond the common agricultural extension practices. Tackling transition processes means sharing knowledge and enhancing capacities for adapting to change in a non-hierarchical or formalized manner (Woodhill 2009), as well as building capacities to design, lead, facilitate and support such processes in ways that lead to real learning and change. In this context, learning networks are key places to create heterogeneous groups of stakeholders which develop mutual trust and social cohesion (Vogelezang et al. 2009).

Following Heleba et al. (2016:180), new agroecological extension practices stress the need of focusing on end-user needs, regarding design and implementation of learning processes; and to "meet the farmers where they are". Other authors stress the difference of adult-learners' needs from those of younger students, thus shaping educational processes focusing on prior experiences and motivations, and practical tools as casestudies or problem based learning (Ota et al. 2006; Franz et al. 2010; Bell and McAllister 2012, cited in Heleba et al. 2016). In this sense, an agroecological training program based on students' real-world interactions could be an agroecological transition trigger (Francis et al. 2012).

Heleba et al. (2016) include the need for practitioners with skills in setting up "relationship architectures". Existing multi-actor networks in study sites are an additional variable which practitioners must address and assess. Experiencing complexity and interdisciplinary perspectives early in the process of defining the problem become an important element of phenomenological learning itself (Lieblein et al. 2012). In this sense, agroecological extension training programs can play the role of a 'hybrid forum', (Elzen et al. 2012) bringing together different localized agri-food system actors (i.e., local authorities, researchers, private actors and food movements). Within such hybrid forums, each actor's vision and interests are confronted with those of the other, serving as a representation of social diversity as it pertains to agri-food systems. Ultimately, this is intended to amplify the interactions among niche and regime-actors and discourses. Responses and arrangements to the complex challenges of agri-food systems need to be built upon a complex network of expertise, subjectivities, and positions. This network includes unequal positions of power and agency regarding 
socio-technical transitions. Within such forums, facilitated by researchers, innovative visions should lead to innovative proposals for transition paths.

The "end-user-needs focusing" approach uncovers a conflict related to the nature of local actors' expressed needs and practitioners' perceived needs. As demonstrated by Freire $(1975,2005)$, the expressed needs of the "oppressed" tend to show a strong "adherence" to oppressors' discourses and interests. Therefore, expressed needs of subaltern actors along the agri-food system often address conventional, close-minded solutions for its sustainability. Freire developed both a methodological (Educaçao Popular) and theoretical (Pedagogia do oprimido) approach to overcoming such adherence, which was also adapted to farming systems as an early criticism of rural extension (Freire 1969). This framework has been recognized as the core of some relevant methodological approaches for sustainable, participatory rural extension, namely Participatory Action-Research, Participatory Rural Appraisal, Farmers' Participatory Research, and the Campesino a Campesino movement (Rhoades and Booth 1982; Bunch 1985; Farrington and Martin 1988; Chambers 1994a, b, c; HoltGimenez 2006; López Vargas et al. 2009; Guzmán et al. 2013; Méndez et al. 2016).

Within the current power structure of European agri-food systems, small local farmers can be considered as a kind of oppressed actors (Marsden and Sonnino 2008; Reed 2008; Bell et al. 2010). Despite small farmers being excluded from globalized agri-food networks, their adherence to oppressors' discourses and practices is observed both as a strong commitment to intensification discourses, and as a rejection of a shift towards more sustainable farming and added-value marketing strategies through alternative food networks (Darnhofer et al. 2005; Padel 2008; Guzmán et al. 2016, Meek 2015; Mendez et al. 2017). In such context, Freire's (2004) proposal to learn to "read the World" while "reading the word" should be at the core of a training program for agroecological extension to overcome such adherence to the globalized, conventional agri-food system. Following Freire's developments, the aim of participatory agroecological transition processes and methods should be, not only to ask the people but to create the intersubjective environment in which people (local communities) develop their critical vision of their world. With this aim, agroecological practitioners should learn how to foster processes of action-reflection-action (Freire 2005) among small farmers and other local, rural actors to activate transitions to agri-food sustainability.

\section{Methodology}

Case study

Agroecology was firstly introduced in Spain through a PhD program which begun in 1996, at Universidad Internacional de Andalucía. Such program tried to bring to Europe the novel developments of agroecology from the Americas, and to train a new generation of Latin-american activists, researchers and policy makers linked to La Vía Campesina and Coordinadora Latinoamericana de Organizaciones del Campo (SevillaGuzmán 2007). Agroecology has later been spread in Spain mostly as a social, anticapitalist movement linked to food sovereignty principles, stronger settled down in the cities than in the countryside (López-García 2015). The interest from the academia and the public institutions towards agroecolgy has been really scarce, since agronomy in Spain is deeply rooted on a productivist ideology. In the last years, a bigger demand from local authorities has led to the development of different projects oriented to 
generate practical tools for what has been named as "political agroecology" (González de Molina, 2013).

In 2012 a group of grassroots food movement activists in Spain organized a Seminar on "Local Agroecological Dynamization" with the aim of developing tools for promoting agroecological transitions within deagrarianized, postindustrial European territories. One of the results of the Seminar was to create a training program on the topic. The Universitat Autònoma de Barcelona grew interested in supporting a university postgraduate training program on LAeD. A multidisciplinary coordination team, including social and environmental researchers on agri-food systems and agri-food activists, developed an action-oriented program with the aim of training agroecological transition promoters. From a multi-actor perspective, targeted groups of students were both agrifood activists (including farmers) and public officers from local and rural development administrations. The first edition of the training program on LAeD was launched in 2014.

The three pillars of the course are: (1) an online training, (2) three meetings, and (3) the development of a research project. The six month online training consists of forum discussions based on the following theoretical and methodological contents: (1) rural sociology, agroecology and food sovereignty, (2) action-oriented social research and participatory methodologies, (3) alternative food networks and access to land, seeds and other resources, and (4) agroecological traditional knowledge. Additionally, practical exercises are included to confront theory with the perceived reality of students, along with the training program. Face-to-face meetings consist of three visits to different agroecological projects in different rural contexts. During these meetings (two full days each) participatory and qualitative research techniques are applied by the students in the context of the visited projects. The meetings include training sessions on facilitation skills through workshop simulations. Throughout the course, the students work on their final research project, which consists of developing a preliminary assessment of a real process, and designing a participatory process to address its prioritized challenges. Progress on the individual projects is collectively discussed on thematic groups during face-to-face meetings.

The training program is conceived as a hybrid forum generating action-reflection-action processes in two dimensions: (1) internal, in which the multi-actor network of students discusses niche-regime interactions; and (2) external, in which students have to generate such processes within their final project in real-world settings.

Data collection and analysis

The methodological design combined quantitative and qualitative methods: a survey questionnaire and in-depth interviews.

For a population universe based on 60 former students who took the postgraduate training program during two years (2014-2015 and 2015-2016) (2 courses x 30 students each course), a sample of 43 individuals answered an online questionnaire survey. The questionnaire was designed with the aim of studying the impact of the program, and it collected data on the individuals' perceptions about their daily work on local development projects. In addition to the classic socio-demographic questions (gender, age, educational background, and occupation), the questionnaire contained three sections: (1) individual motivations to enroll in the program; (2) perceived impacts (real 
or potential) on students' everyday work; and (3) employability of the individuals. The analysis consisted of univariate frequency analysis. In-depth interviews were performed with a sample of these same ex-students $(\mathrm{N}=16)$ selected according to two main criteria: (1) type of institution or organization developing the projects (public or private); and (2) territorial level (i.e., municipal, county/province). Interviews were recorded, and interviewees were coded to guarantee confidentiality. The codes include reference to whether they work in the public sector (Pub), or in the private or non-profit sectors (Prv), and their institution/organization territorial level (county/province level: $\mathrm{C}$; or municipal level: M). All of the interviewees were working in the agri-food and/or rural development fields when the survey was answered, and they were developing projects related to such issues (see Table 1). We followed Helen (2011) and coded relevant text passages from the voice records and notes using no predefined codes.

$<<$ Table 1 about here >>

\section{Potential impacts of LAeD training on individuals and institutions}

The results were structured according to two types of the potential effects of the analyzed training program. The first related to the impacts on the individual level (i.e., local development practitioners themselves), and the second on the institutional level (i.e., the influence of the program in the local development institutions).

Reconfiguration of individual practices, concepts, and tools

The 43 individuals of our sample are involved in local and/or agri-food development as professionals or activists. The main motivations they mention for enrolling in the training program include: (1) to increase their theoretical knowledge on agroecology and/or food sovereignty (95\%); (2) to increase their knowledge on participatory methods (81\%) and other social research methods (68\%), (3) and to connect with people and professionals related to these areas $(71 \%)$.

\section{Acquiring theoretical frameworks and methodological capacities and skills}

Results show that students positively value the acquisition of new knowledge. Thus, students with a technical-scientific background tend to value knowledge related to social, political, and cultural aspects, and vice versa:

"[I value] The social part, because of my background, is what I was lacking. The postgraduate course opened perspectives unknown for me, where I didn't have this base. And you have a point of departure. This has allowed providing me a theoretical framework to the process in [my village]" (PubM4, background on agricultural engineering)

"These are techniques applicable; I turn to the links especially on participatory methods, now I have a much broader range of participation tools" (PubC4)

A majority of students claim to have covered new subjects after studying the training $(51 \%)$ or expect to cover them shortly $(61 \%)$, while $79 \%$ state that approaches and practices they were already familiar with have been reinforced. These results mean that most students were already familiar with the agroecological approach, to which the 
training has added new topics, and, most of all, it has provided them with greater confidence in its application, particularly within public employees (63\%). At the same time, results show changes in students' attitudes and perspectives: 92\% state to have modified their perspective on local and/or rural development, $85 \%$ state to have modified their perspective on what the role of public policy in the agri-food sector should include, and $74 \%$ state to have modified their perspective on the agri-food system. In all cases, changes have been made towards an agroecological and food sovereignty approach.

Students' perceptions of the training program differ according to their profiles. Public officers (more than the half of students) can be classified in two main groups: (1) those who had previous knowledge on the agroecological approach and asked permission from their institution to join the program, and (2) those who were encouraged (or obligated) by their institutions to join. While the first group expresses to be satisfied with the acquisition of methodological tools and a more systematic conceptual framework, the second group highlights the discovery of new approaches to agri-food systems, rural development, and the role of public administration on agri-food system sustainability. A third group, composed of food activists and organic farmers, acknowledged the reconfiguration of their perceptions about other agri-food system actors' roles and visions towards agroecological transition. This reconfiguration leads to the acquisition of a more complex perspective on agri-food system transitions, and therefore, raises the expectation for new methodological tools to be used in the actors' daily work.

\section{Re-framing local development projects}

Interviewees point out that several changes were triggered by their involvement in the projects, due in particular to the training, especially those regarding participatory approaches. They have applied some of the methods acquired in training (i.e., PubC3 and PubC2), as well as certain guidelines for the design of participatory processes. Such methods have been mentioned to be useful to generate mutual trust between actors in the territory, as well as to engage new actors in the process, generally adapting them to context specificities (i.e., PubC2, PrvM3, PrvC1, PrvC2). The practical cases and experiences visited during the training program have generated a greater self-confidence among students' practices, have helped them to identify key aspects of the processes in which they are involved, and have served as a comprehensive transition perspective for participatory processes design (i.e., PubM4; PubC4).

In some cases, acquired participatory methods have made it possible to redirect deadlocks in the transition processes, to increase agility and efficiency, and to better manage human relationships in the local development projects they are developing (PubM4). The idea of including a greater diversity of actors (e.g., the education community, food coops, extra-local or conventional farmers) in the processes is mostly repeated (PubC2, PubC3). The approach of the training program has opened communication channels amongst actors who previously did not participate in the processes or did not even mutually acknowledge themselves as valid interlocutors. In particular, this was the case for some local authorities and civic organizations (i.e., PrvC3): 
"I have seen that there are professionals in the public sector who are not familiar with the concepts of the training [program], but [I have seen] that they evolve... and this is why I have changed my perspective on the regional food council project, because I see there is technical staff in the region who can evolve..." (PrvC3)

Most interviewees state their intention to engage new actors in future activities within their projects, as well as to reinforce the use of participatory methods (i.e., PubC2; PrvC2; PubC3; PubC4). Specifically, they mention the possibility of exploring the 'Campesino a Campesino' approach (PrvC1), a participatory diagnosis of the livestock sector (PrvC4), formal participatory bodies (e.g. steering group, monitoring committee) in charge of the territorial diagnosis and the elaboration of the action plan (PrvC2), or a participatory council with a diversity of actors (PubM2).

Influence on institutions

\section{Emergent attitudes among institutional representatives}

Interviewees perceive some changes in the positions of the public institutions involved in the training program or in those they work in. Indeed, increasingly positive attitudes towards agroecological projects are mentioned, which has the effect of generating more activities within this framework in the related territories (PubC4). Several cases have been mentioned in which participatory methods have generated great interest amongst the institutions promoting projects (i.e., PrvC2; PubM4). In some cases, the LAeD approach has provided a more structured methodological approach, which has been successfully applied in previously failed processes of local dynamization, and have been redirected in line with PAR and the agroecological transitions approach after the technical staff went through the training (i.e., PrvM1).

Interviewees also point out an increase in agroecological sensitivity amongst some political and technical staff members of both urban and rural local authorities (PubM1; PrvM2; PubM2), or they mention that at least interest for other points of view has been triggered amongst the institution promoting the projects (PubC1). It has also been stated that initiatives related to the training program have raised the interest of regional agrarian administrations (the Catalan Agriculture Department) for other approaches (i.e., agroecological) (PrvC1). An interesting finding is that public institutions interested in applying the agroecological and participatory approaches to their local development programs are fundamentally territorial (e.g., city councils, regional councils, provincial councils) but not directly agrarian. This is mainly due to the potential of the approach regarding local (territorial) administration competences over environmental conservation, territorial planning, city planning, economic promotion or employability. Sectorial agrarian institutions have shown themselves to be less open to adopting agroecological approaches.

\section{New alliances or multi-actor network reconfigurations}

Relationships between farmers and public administration officers seem to be improved through the training program approach (i.e., generating greater trust), especially in the case of initiatives not promoted by the administration or in the case of private technical assessment for the public sector (PrvC2; PrvM3; PrvM1; PrvC1). In one of these cases, 
it is explicitly stated that the LAeD approach has diminished the strong distrust previously existing between producers and the public administration (mainly due to previous experiences of top-down approaches to local development), through the set-up of new contexts and ways of communication and cooperation (PrvM3). Also, in several cases, new actors have engaged in the processes, either occasionally and/or informally, or permanently and/or formally. Only $39 \%$ of the questionnaire respondents state that, after their involvement in the training program, new alliances between social groups and/or the administration have occurred. Furthermore, 64\% state that such alliances could be developed in the near futures, and 50\% consider that already existing alliances have been reinforced.

The creation of alliances with new actors to develop joint actions is one of the most valued changes, both by the local authorities and by civic organizations (PubM2; PrvC3). Such new alliances are established with local administration representatives (PrvC3), schools (primary education) and other interested people in the region (PubC3). Additionally, the increase of the relationships between local authorities and other public administrations in the same region has been highlighted (PubM1; PrvC2; PrvM1), as well as that between private and social institutions such as food coops, between food coops and organic producers' groups (PubC4), and between the local authorities and farmers' groups. This last alliance has been mentioned in several cases as a remarkable change (PrvM3; PrvC1; PubM2; PrvC4). In one particular case (PubC2), the constitution of a participatory, food governance formal structure was referred to, in which several municipalities of the region enrolled together with producers and local associations to develop common goals and projects.

\section{Local governments internal re-configurations}

A case was reported in which the public administration explicitly included agroecology as a framework for local development in a regional center for economic and entrepreneurial promotion (PrvM1). Examples also exist in which the public administration sponsored a project for the creation of an agroecological agrarian extension mobile office (PrvM3). In other cases, a sector of the institution (e.g., department, council) undertook an agroecological approach and is trying to extend it to other areas in the same institution (e.g., town hall) (PubM2). Some institutions (i.e. Cardedeu and Sant Cugat del Vallés City Councils, Barcelona) have hired new staff as "Local Agroecological Dynamizators", to develop agroecological initiatives, justifying the positions for their potential to generate employment at the local level in a time of increased unemployment and social exclusion (due to the impact of the economic crisis) (PrvC2).

In several cases, interviewees claim that it is difficult for institutions to change because their structures are too rigid and unfavorable to new perspectives (PubM4; PubM1), or because the technical staff working with agri-food issues usually have such a background that their approach is very different than the agroecological one (PrvC1). In this sense, the interactions among students, and specifically public officers during peerto-peer exchange served as a very useful tool to generate changes in the officers' perceptions of LAeD potential. In other cases, local authorities' officers appreciated the feasibility of applying the LAeD approach to their work. Conversely, local organic farmers linked to food movements did not see this possibility due to the strong resistance of the majority of local, conventional farmers to organic farming practices 
(PrvM3). Finally, it is also stated that the introduction of participatory procedures sometimes generates concern in the public institutions because it is seen as time consuming activity, and it involves changing current modes of operation (PubM1), thus generating internal resistance to change.

\section{Discussion: agroecology training as 'hybrid forums' for regime reconfigurations?}

We argue that the above described LAeD training program can be conceived as a hybrid forum, a convergence space where different actors meet, discuss and identify disruptive innovations within local agri-food systems. A 'hybrid forum' is the place where 'nicheactors' can be transformed into 'hybrid actors,' key actors in transferring niche innovation to the socio-technical regime level (which eventually would be reconfigured). Indeed, the feedback obtained from former students shows that the postgraduate training program had an impact not only regarding individual concepts, practices, and tools but also in their working environments (i.e., the institutions in which students work at the moment of the training or after).

According to our results, the LAeD teaching methodology is built upon actionreflection-action processes in which reversive approaches to the analyzed challenges are applied (Villasante 2006). Such analysis is made collectively from the students' own previous experience in conjunction with the new knowledge and experience generated during the training. This diverse learning space in which niche and regime-actors come together generates a learning process in which both typologies can be reconfigured. Thus new ways of mutual knowledge and recognition (of each other's challenges, values, and positions) emerge which can be applied later in real life multi-actor networks dynamization.

Within the hybrid forum, students can set up creative interactions between niche and regime-actors to become hybrid actors and may act as innovation brokers (Galli and Brunori 2011). Some of the students of the training program become hybrid actors through a twofold process. First, through their final postgraduate thesis, students have to confront LAeD theories and methods with the real world in territories in which they usually work and/or live. Second, within the multi-actor network, they participate in action-reflection-action processes in which they confront their practical experiences on the field with other actors' values, visions, and positions. Such twofold, collective action-reflection-action process acts, as stated by Freire $(2004,2005)$, as a way to learn to "read the World" with their own, innovative words at the same time that they learn "to read the word" (i.e., on participatory methods and sustainable agri-food systems). It is within this reconfiguration of the way students understand their work and their role within territories that they can learn how to tackle transition processes, in order to generate understanding among local actors, enhance capacities and support processes which lead to real learning and change (Woodhill 2009; Vogelezang et al. 2009; Darnhofer 2015). Thus, such shift leads students to occupy hybrid positions between niche and regime-actors to generate new niche-regime interactions which can lead to innovation anchoring and linking. Our results show several clear cases of rural development officers changing their views and starting new projects with agroecological orientation, as well as cases of agroecological activists changing their attitudes and accepting the possibility of cooperation with public services. 
Also, hybrid forums have been identified as a key tool to develop new approaches to overcome previous frameworks which reproduce agri-food system agency inequalities (Smith 2007). Action-reflection-action processes within the program have led to the recognition of the role of small stakeholders (primarily farmers) as a kind of 'marginal actors' within local agri-food systems. Therefore these processes have uncovered the need for actions in which such actors get visibility and a stronger role, as recognized in previous research (Meek 2015; Mendez et al. 2017). Both participatory methods and contents such as traditional ecological knowledge or alternative food networks have been recognized with a strong potential to build up 'small actors' empowerment within agroecological transitions. In short, according to our results, LAeD training has been understood by students as an adequate tool to strengthen previous dynamics of agroecological transitions, through the improvement of their capabilities, selfconfidence and applied knowledge.

As the training program is explicitly (but not only) oriented to local administration officers and it is officially associated with several local authorities (and it is offered by a public university), it may act as an institutional anchoring space (Elzen et al. 2012). Access to such institutional anchoring has been recognized as a high stage of sociotechnical regimes reconfiguration (Bui et al. 2016). In this context, the training would represent an 'institutional innovation niche' by generating potential processes of niche anchoring and niche-regime linking. In this regard, the majority of the feedback collected from local administration officers shows a change in their viewpoints concerning the role of sustainable agrarian production for local development, in line with local agroecological proposals embedded in the territory. Some of the collected views are oriented towards the need to move from the rural development socio-technical regime focused in activities' diversification, which entails a deagrarianization dynamic (Marsden and Sonnino 2008; Guzmán et al. 2016), towards a new regime in which sustainable agrarian activity would be at the core of rural economic activity. Thus, we can say that through a training program based on participatory and multi-actor learning processes, the regime-actor nature of local administration officers can shift to positions of, at least, hybrid actors in agroecological transition processes.

Concerning agri-food systems, Wheeler (2008) identified agricultural administration officers as being a strong reluctant actor against sustainability transitions. Our results support this hypothesis showing that transition processes seem to be more difficult regarding agricultural administration officers. From the perspective of our theoretical framework, this may be because the agrarian administration is a key node for the reproduction of hegemonic regimes, and therefore, it could be situated as a regimeactor.

As for local administration officers, on the contrary, our research suggests they may act as formal hybrid actors. This role as hybrid actors is due to their twofold nature as niche and regime-actors (Elzen et al. 2012). It is also as a result of motivations and skills adopted to create new multi-actor alliances (niche network-anchoring) for agri-food systems sustainability (Roep and Wiskerke 2004; Elzen et al. 2012; Díaz et al. 2013). Public actors without direct competences on agriculture, such as local administrations and municipalities, would then be more exposed to become hybrid actors, and thus to integrate hybrid forums and catalyze niche-regime interactions through institutional anchoring. In this sense, the enrollment of local authorities (e.g., Àrea Metropolitana de Barcelona, Diputació de Barcelona, or several city councils) as sponsors within the training program represents a major opportunity. In fact, such institutions demand not 
only the training for their officers, but also the cooperation of LAeD students to develop innovative approaches for very specific challenges they face, such as the development of advisory and participatory processes on strategic land planning, or the design and implementation of agroecological transition processes.

The period analyzed is very short (only two years), and the sample is very limited, as our research has only exploratory purposes. In any case, it is possible to identify wider processes that provide a window of opportunity to push for socio-technical food regime reconfigurations, at least at the local scale (municipal or regional). Despite the chronic crisis of small actors involved in globalized agri-food systems, the recent crisis of local development itself (especially after the last decade of financial crisis and related austerity measures) is pushing local authorities (both urban and rural) to adopt and promote new approaches to local economies. As mentioned above, it is mainly local governments (city councils, county councils, provincial councils, metropolitan entities, etc.) that most tend to bet on alternative models of socioeconomic development. These institutions are the first line in dealing with the social urgency caused by the economic crisis which led to the exclusion and impoverishment of many due to mass unemployment, evictions, energy shortages, food poverty, etc.

Although local governments tend to have fewer resources available, they are closer to the population and are taking on a leading role in managing the effects of the crisis. All of this creates a context in which agroecological initiatives can play an important role (Pomar-León and Tendero-Acín 2015), and some public administrations are beginning to consider them as useful formulas for improving social inclusion (e.g., job creation or lifestyle changes toward sustainability). As an example, there is an emergence of social gardens and other forms of urban and peri-urban agriculture (Domene et al. 2016), along with increased social agriculture initiatives throughout the territory (Guirado et al. 2017). This emergence has been demonstrated by the projects promoted by former students of the training program.

The commitment to new local agroecological policies is much more intense in those municipalities where government teams have become aware of the importance of the environmental, energy and financial crisis (López-García et al. 2017) and are willing to look for other models of economic and social development. In this sense, local authorities need for innovative local development approaches are opening the sociotechnical landscape to amplify the impact of the agroecological innovations generated by niche-actors. New alliances of agroecological research groups, food movements and non-agricultural, local authorities are not at the center of food regime, but, perhaps, for this reason, they are more flexible and sensitive to regime reconfigurations and can become hybrid, bridge actors for agroecological transitions upscaling and outscaling.

\section{Conclusions: deepening multi-actor networks role within agroecological transitions}

In this paper, we have suggested some insights on the way agroecological university training programs can influence food regime reconfiguration, focusing on multi-actor relationships from a multi-level perspective. With this aim, participatory methodologies have shown a high performative potential within the learning process itself.

The training program has also shown a high performativity on the reconfiguration of visions of local development and the different agri-food system's actors (e.g., the introduction of innovative narratives and action proposals within rural and local 
development practitioners and authorities). The set-up of training programs conceived as hybrid forums collecting an important diversity of agri-food system actors can be an effective tool to promote hybrid-actor profiles, both in students with an activist or farmer background, as well as in practitioners of local or agricultural administration or extension bodies. Within such hybrid forums, peer-to-peer interactions among the different actors act as an important change vector in a twofold way: (1) as a way to generate confidence among peers; and (2) as a way to confront different visions within the local agri-food systems.

The creation of hybrid forums is positive regarding such transitions, both at individual and collective levels. Action-reflection-action processes generate a resignification and reconfiguration of practices among students, which can be translated into their realworld environments, thus leading to innovation anchoring. The conformed hybrid actors act as a bridge between different positions and practices in the real world, facilitating the understanding and latter cooperation between different actors. This lead to collective innovation processes.

The methodological design of the LAeD training program addresses niche-regime interactions in different ways. On one side, providing both theoretically and methodologically specific tools oriented to the reconfiguration of visions on agri-food systems and multi-actor networks and focusing on social creativity processes can serve to overcome the lock-ins posed by regime-actors and regime-values against regime reconfiguration. On the other side, through a learning process within a mockup of the actors' diversity found in real transition processes to sustainable local agri-food systems, thus useful to experience the complex relations to be found in real world.

Therefore, the training offers a potential way to spread and accelerate niche-anchoring, at least, through a niche-regime linking along two different routes. Firstly, as a network anchoring tool generating directly and indirectly multi-actor networks, both along the course and through the final thesis developed on the real world. Secondly, as an institutional anchoring process as far as it includes agroecology in the toolkit of rural development officers and other practitioners. At the end, the training program may be understood as an "institutional innovation niche", as it explicitly promotes innovation processes within different public institutional bodies (both agricultural and territorial) which collaborate with the training program themselves. Thus, the training places agroecological innovations (both farming practices related issues and agroecological transitions methodological issues) at the core of the tension between regime-actors and niche-actors.

The transformative potential of the training program, in terms of niche-regime anchoring, is favored by the current crisis-related context of growing receptivity among different public bodies towards sustainability innovations within the agri-food system. The rise of some 'new municipalist' local governments in several Spanish big cities such as Barcelona, València, Madrid, Zaragoza, Palma de Mallorca and others- and some regional governments -Comunitat Valenciana and Navarra-, with a novel and strong commitment to sustainable food policies opens a wide window of opportunity for sustainability transitions in the socio-technical landscape (López-García et al. 2017). Thus, addressing power issues through political action can become a strong support for such transitions, seeking for new alliances with those public bodies which could become sensible to agroecological transitions. The discussion on MLP applied to agroecological transitions can be therefore connected with the discussion on 'political agroecology', expressed as the need of "political and institutional mediation [...] (and) the 
development of public policies that drive the agroecological transition forward" (González de Molina, 2013:56). The way we have tried to link both issues -nicheregime interactions and political agroecology- is through (1) encouraging students to work on real-world processes; and (2) reinforcing dissemination activities of LAeD projects' results, with special regard to policy-makers.

The main feature that could differentiate this training from others is its marked hybrid forum character. It has been designed and promoted by a mix of academics and activists, and a great effort has been made to mix students working in local development institutions with students in the agroecological sector (activists and farmers). The teaching methodology encourages the interaction between student profiles with very different conceptual backgrounds. The training program is designed as a meeting place in such a way that it promotes intense interactions among the participants, generating bonds of trust between people who occupy key positions in their respective fields (public administrations, NGO activists of agroecology, farmers' cooperatives, etc.), but also provides them with real-world agroecological transition experiences, that turn some students into hybrid actors. The projects developed within the training, with the support of local institutions, have practical implications by implementing agroecological initiatives in the territories. However, we should be aware that hybrid forums can evolve both toward conventionalization of agroecology or toward the strengthening of its transformative potential. The impacts of the training open new possibilities to upscaling and outscaling agroecology, but this will not be promoted by hybrid actors alone, but mostly, as suggested by other scholars (González de Molina 2013; Levidow et al. 2014; Meek 2017) by niche-actors and food movements, and reconsidering the current topdown agri-food policies.

\section{References:}

Altieri, M.A. 1983. Agroecología. Bases científicas para una agricultura sustentable. Montevideo: Nordan Comunidad.

Bell, M.M., S.E. Lloyd and C. Vatovec. 2010. Activating the Countryside: Rural Power, the Power of the Rural and the Making of Rural Politics. Sociologia Ruralis 50 (3): 205-224.

Bui, S., A. Cardona, C. Lamine and M. Cerf. 2016. Sustainability transitions: Insights on processes of niche-regime interaction and regime reconfiguration in agri-food systems. Journal of Rural Studies, 48: 92-103.

Bunch, R. 1985. Dos mazorcas de maiz: una guía para el mejoramiento agrícola orientado hacia la gente. Oklahoma City, US: World Neighbours.

Chambers, R. 1994a. Participatory Rural Appraisal (PRA): Challenges, Potentials and Paradigm. World Development 22 (10): 1437-1454.

Chambers, R. 1994b. The origins and Practice of Participatory Rural Appraisal. World Development 22 (7): 953-969.

Chambers, R. 1994c. Participatory Rural Appraisal (PRA)-challenges, potentials and paradigm. World Development 22, 9, pp. 1437-1454. 
Darnhofer, I. 2015. Socio-technical transitions in farming. Key concepts. In Transition Pathways towards Sustainability in Agriculture. Case studies from Europe, Eds. Sutherland, L.A., I. Darnhofer, G. Wilson and L. Zagata, 17-32. Oxfordshire, UK: CABI.

Darnhofer, I., W. Schneeberger and B. Freyer. 2005. Converting or not converting to organic farming in Austria: Farmer types and their rationale. Agriculture and Human Values 22 (1): 39-52.

Diaz, M., I. Darnhofer, C. Darrot and J.E. Beuret. 2013. Green tides in Brittany: What can we learn about niche-regime interactions? Environmental Innovation and Societal Transitions 8: 62-75.

Domene, E. (coord.). 2016. Agricultura Metropolitana. Agricultura urbana $i$ periurbana a l'àmbit metropolità de Barcelona: beneficis econòmics, socials $i$ ambientals. Barcelona, España: Institut d'Estudis Regionals i Metropolitans de Barcelona.

Duru, M., O. Therond and M. Fares. 2015. Designing agroecological transitions; A review. Agronomy for Sustainable Development 35 (4): 1237-1257.

Elzen, B., F.W. Geels, C. Leeuwis, B. van Mierlo. 2011. Normative contestation in transitions 'in the making': Animal welfare concerns and system innovation in pig husbandry. Research Policy 40: 263-275.

Elzen, B., B. van Mierlo, C. Leeuwis. 2012. Anchoring of innovations: Assessing Dutch efforts to harvest energy from glasshouses. Environmental Innovation and Societal Transitions 5: 1- 18 .

Farrington, J. and A.E. Martin. 1988. Farmer participatory research: A review of concepts and recent fieldwork. Agricultural Administration and Extension 29 (4): 247-264.

Francis, C., T.A. Breland, E. Østergaard, G. Lieblein and S. Morse. 2012. PhenomenonBased Learning in Agroecology: A Prerequisite for Transdisciplinarity and Responsible Action. Agroecology and Sustainable Agri-food Systems 37 (1): 6075.

Francis, C., G. Lieblein, S.R. Gliessman, N. Creamer, R. Harwood, L. Salomonsson, J. Helenius, D.H. Rickerl, R. Salvador, M.H. Wiedenhoeft, C. Flora, S.R. Simmons, M.A. Altieri and R. Poincelot. 2003. Agroecology. The ecology of agri-food systems. Journal of Sustainable Agriculture 22 (3): 99-118.

Freire, Paulo. 1969. ¿Extensión o comunicación? La concientización en el medio rural. Mexico DF, México: Siglo XXI.

Freire, Paulo. 1975. Pedagogia del oprimido. Madrid, España: Siglo XXI.

Freire, Paulo. 2004. La importancia de leer y el proceso de liberacion. Mexico DF, México: Siglo XXI.

Freire, Paulo. 2005. Pedagogía de la esperanza: Un reencuentro con la pedagogía del oprimido. Mexico DF, México: Siglo XXI.

Galli, F. and G. Brunori. 2011. Knowledge brokerage to promote sustainable food consumption and production: linking scientists, policymakers and civil society 
organizations. Report of the FOODLINKS project. www.foodlinkscommunity.net. Accessed 25 july 2017.

Geels, F.W. 2002. Technological transitions as evolutionary reconfiguration processes: a multi-level perspective and a case-study. Research Policy 31: 1257-1274.

Geels, F.W. 2010. Ontologies, socio-technical transitions (to sustainability), and the multi-level perspective. Research Policy 39: 495-510.

Geels, F.W. 2011. The multi-level perspective on sustainability transitions: Responses to seven criticisms. Environmental Innovation and Societal Transitions 1: 24-40.

Gliessman, S.R. 2002. Agroecología: procesos ecológicos en agricultura sostenible. Turrialba, Costa Rica: CATIE.

Gliessman, S. R. and M. Rosenmeyer, eds. 2010. The conversion to sustainable agriculture. Principles, processes and practices. Boca Ratón, US: CRC Press.

González de Molina, M. 2013. Agroecology and Politics. How To Get Sustainability? About the Necessity for a Political Agroecology. Agroecology and Sustainable Agri-food Systems 37 (1): 45-59.

Guirado, C., N. Valldeperas and A. Tulla. 2017. L'agricultura social a Catalunya. Desenvolupament local i ocupació per a col-lectius en risc d'exclusió social. Tarragona, España: Cossetània.

Guzmán, G.I., M. González de Molina and E. Sevilla-Guzmán. 2000. Introducción a la agroecología como desarrollo rural sostenible. Madrid, España: Mundi-Prensa.

Guzmán, G.I., D. López-García, L. Román and A.M. Alonso. 2013. Participatory Action Research in Agroecology. Building organic food networks in Spain, Agroecology and Sustainable Agri-food Systems 37 (1): 37: 127-146

Guzmán, G.I., D. López-García, L. Román and A.M. Alonso. 2016. Participatory Action Research for an Agroecological Transition in Spain. In Agroecology: A Transdisciplinary, Participatory and Action-oriented Approach, Eds. V.E. Méndez, C.M. Bacon, R. Cohen, S.R. Gliessman, 140-160. Boca Ratón, US: CRC Press.

Heleba, D., V. Grubinger and H. Darby. 2016. On the Ground. Putting Agroecology to Work through Applied Research and Extension in Vermont. In Agroecology: A Transdisciplinary, Participatory and Action-oriented Approach, Eds. V.E. Méndez, C.M. Bacon, R. Cohen, S.R. Gliessman, 177-192. Boca Ratón: CRC Press

Holt-Gimenez, E. 2008. Campesino a campesino: Voces de Latinoamérica. Movimiento Campesino para la Agricultura Sustentable. Managua, Nicaragua: SIMAS.

Lamine, C. 2011. Transition pathways towards a robust ecologization of agriculture and the need for system redesign. Cases from organic farming and IPM. Journal of Rural Studies 27(2): 209-219.

Levidow, L., M. Pimbert y G. Vanloqueren. 2014. Agroecological Research: Conforming or Transforming the Dominant Agro-Food Regime? Agroecology and Sustainable Agri-food Systems 38: 1127-1155. 
Lieblein, G., T.A. Breland, C. Francis and E. Østergaard. 2012. Agroecology education: action-oriented learning and research. Journal of Agricultural Education and Extension 18(1): 27-40.

Lobley, M., A. Butler and M. Reed. 2009. The contribution of organic farming to rural development: An exploration of the socio-economic linkages of organic and nonorganic farms in England. Land Use Policy 26: 723-735.

López-García, D. 2015. Producir alimentos, reproducir comunidad. Redes alimentarias alternativas como formas económicas para la transición social y ecológica. Madrid, España: Libros en Acción.

Lopez-Garcia, D. and G.I. Guzman Casado. 2014. Metodologias participativas para la transicion agroecologica. Madrid, España: Sociedad Española de Agricultura Ecologica.

López-García, D., L. Calvet-Mir, J. Espluga, M. Di Masso, G. Tendero-Acin and A. Pomar-León. 2015. La dinamización local agroecológica como estrategia para la construcción de soberanías locales. Ecologia Politica 49: 28-34

López-García, D, P.M. Herrera, N. Alonso, J. Mérida and J.M. Pérez. 2017. 'Cities for Agroecology' Networks in Europe and Spain. Urban Agriculture 33: 55-57.

López Vargas, G., M. Ardón and E. Tomás Pérez. 2009. Agroecología práctica. Tegucigalpa, Nicaragua: LITHOCOM.

Marsden, T. and R. Sonnino. 2008. Rural development and the regional state: Denying multifunctional agriculture in the UK. Journal of Rural Studies 24: 422-431.

Meek, D.. 2015. The cultural politics of the agroecological transition. Agriculture and Human Values 33 (2): 275-290.

Méndez, V.E., C.M. Bacon, R. Cohen. 2016. Introduction: Agroecology as a transdisciplinary, Participatory and Action-oriented Approach. In Agroecology: A Transdisciplinary, Participatory and Action-oriented Approach, Eds. V. E. Méndez, C.M. Bacon, R. Cohen, S.R. Gliessman, 1-22. Boca Ratón, US: CRC Press.

Méndez, V.E., M. Caswell, S.R. Gliessman, R. Cohen. 2017. Integrating Agroecology and Participatory Action Research (PAR): Lessons from Central America, Sustainability 9 (5): 705; doi:10.3390/su9050705

Milestad, R., R. Bartel-Kratochvil, H. Leitner and P. Axmann. 2010. Being close: The quality of social relationship in a local organic cereal and bread network in Lower Austria. Journal of Rural Studies 26 (3): 228-240.

Neumeier, S. 2012. Why do Social Innovations in Rural Development Matter and Should They be Considered More Seriously in Rural Development Research? Proposal for a Stronger Focus on Social Innovations in Rural Development Research. Sociologia Ruralis 52 (1): 48-69.

Helen, N. 2011. Conducting research in conservation. Social science methods and practice. London, UK: Routledge. 
Padel, S. 2001. Conversion to Organic Farming: A Typical Example of the Diffusion of an Innovation? Sociologia Ruralis 41(1): 40-61.

Padel, S. 2008. Values of organic producers converting at different times: results of a focus group study in five European countries. International Journal of Agricultural Resources, Governance and Ecology 7 (1-2): 63-77.

Ploeg, J.D. and T. Marsden. 2008. Unfolding webs. The Dynamics of Regional Rural Development. Assen, NL: Van Gorcum.

Pomar-León, A. and G. Tendero-Acín. 2015. Ja Volem el Pa Sencer. Respostes a la pobresa alimentària en clau de Sobirania Alimentària. Barcelona, España: ASAC!

Reed, M. 2008. The rural arena: the diversity of protest in rural England. Journal of Rural Studies 24 (2): 209-218.

Rhoades, R.E. and R. Booth, 1982. Farmer-back-to-farmer: a model for generating acceptable agricultural technology. Agriculture Administration 11: 127-137.

Roep, D. and J.S.C. Wiskerke. 2004. Reflecting on novelty production and niche management in agriculture. In Seeds of Transition, eds. J.S.C. Wiskerke and J.D. van der Ploeg, 341-356. Assen, NL: Van Gorcum.

Rogers, E. M. 1962. Diffusion of innovations. New York: The Free Press.

Röling, N.G., and M.A.E. Wagemakers, eds. 1998. Facilitating Sustainable Agriculture: Participatory Learning and Adaptive Management in Times of Environmental Uncertainty. Cambridge, UK: Cambridge University Press.

Sanderson B., A.A. and A.A.R. Ioris. 2017. Addressing the knowledge gaps in agroecology and identifying guiding principles for transforming conventional agri-food systems. Sustainability 9:330. doi:10.3390/su9030330

Sevilla-Guzmán, E. 2007. De la sociología rural a la agroecología. Barcelona, España: Icaria.

Smith, A. 2007. Translating sustainabilities between green niches and socio-technical regimes. Technology Analysis \& Strategic Management 19 (4): 427-450.

Tisenkopfs, T., G. Brunori, K. Knickel, and S. Sumane. 2009. Co-production of rural innovation: towards an enriched theoretical model. In Innovation processes in agriculture and rural development. Results of a cross-national analysis of the situation in seven countries, research gaps and recommendations, eds. Knickel, K., Tisenkopfs, T. and Peter, S. Sumane, 129-159. IN-SIGHT project. www.insightproject.net. Accessed 10 june 2017.

Ventura F., G. Brunori, P. Milone and G. Berti. 2008. The Rural Web: A Synthesis. In Unfolding webs, The Dynamics of Regional Rural Development, eds. JD Ploeg and T. Marsden, 149-174. Assen, NL: Van Gorcum.

Villasante, T.R. 2006. Desbordes creativos. Madrid, España: La Catarata.

Vogelezang, J., A. Wals, B. van Mierlo and F. Wijanads. 2009. Learning in networks in Dutch agriculture: stimulating sustainable development through innovation and change. In Transitions towards sustainable agriculture and food chains in peri- 
urban areas, eds. K. Poppe, C. Termeer, and M. Slingerland, 93-111. Wageningen, NL: Wageningen Academic Publishers.

Wezel, A., H. Brives, M. Casagrande, C. Clément, A. Dufour and P. Vandenbroucke. 2015. Agroecology-Territories: Places for Sustainable Agriculture and agri-food systems and Biodiversity Conservation. Agroecology and Sustainable agri-food systems 40 (2): 132-144.

Wheeler, S.A. 2008. What influences agricultural professionals' view towards organic agriculture? Ecological economics 65 (1): 145-154.

Woodhill, J. 2009. Institutional innovation and stakeholder engagement. Linking transition management in the North with development in the global South. In Transitions towards sustainable agriculture and food chains in peri-urban areas, eds. K. Poppe, C Termeer and M. Slingerland, 273-291. Wageningen: Wageningen Academic Publishers. 
Table 1: Topics, territories, and institutions related to projects developed by interviewees.

\begin{tabular}{|c|c|c|}
\hline Code & Institution (Region) & Project \\
\hline PubC1 & $\begin{array}{l}\text { Area Metropolitana de } \\
\text { Barcelona (Catalunya) }\end{array}$ & $\begin{array}{l}\text { Land planning regarding agricultural potential } \\
\text { within Metropolitan Area of Barcelona }\end{array}$ \\
\hline PubC2 & $\begin{array}{l}\text { Consell Comarcal del Vallès } \\
\text { Oriental (Catalunya) }\end{array}$ & $\begin{array}{l}\text { Local landraces, cooperative seed bank } \\
\text { promotion }\end{array}$ \\
\hline \multirow[t]{2}{*}{ PubC3 } & \multirow[t]{2}{*}{$\begin{array}{l}\text { Consorci del Lluçanés } \\
\text { (Catalunya) }\end{array}$} & $\begin{array}{l}\text { Prospection and promotion of local landraces } \\
\text { crop and interchange networks }\end{array}$ \\
\hline & & $\begin{array}{l}\text { 'Local milk route' touristic development project, } \\
\text { integrating farmers, tourism and catering sectors }\end{array}$ \\
\hline PubC4 & $\begin{array}{l}\text { Local Action Group 'La } \\
\text { Manchuela' (Castilla-La } \\
\text { Mancha) }\end{array}$ & $\begin{array}{l}\text { Set up and accompaniment of local network of } \\
\text { farmers and consumers for development of local } \\
\text { food networks }\end{array}$ \\
\hline $\begin{array}{l}\text { PubM } \\
1\end{array}$ & $\begin{array}{l}\text { St. Cugat del Vallés City } \\
\text { Council (Catalunya) }\end{array}$ & $\begin{array}{l}\text { Community Urban Gardens program } \\
\text { participatory design }\end{array}$ \\
\hline \multirow[t]{2}{*}{$\begin{array}{l}\text { PubM } \\
2\end{array}$} & \multirow[t]{2}{*}{$\begin{array}{l}\text { València City Council (Pais } \\
\text { Valencià) }\end{array}$} & $\begin{array}{l}\text { Set up of Municipal Food Council for València } \\
\text { City }\end{array}$ \\
\hline & & $\begin{array}{l}\text { LAeD for agroecological transition in three } \\
\text { Valencia City’s agricultural districts }\end{array}$ \\
\hline $\begin{array}{l}\text { PubM } \\
3\end{array}$ & Ea City Council (Euskadi) & $\begin{array}{l}\text { Local development participatory strategy for } \\
\text { BIZIASARE Association-Busturialdeko Garapen } \\
\text { Iraunkorrerako Elkartea }\end{array}$ \\
\hline $\begin{array}{l}\text { PubM } \\
4\end{array}$ & $\begin{array}{l}\text { Orduña City Council } \\
\text { (Euskadi) }\end{array}$ & $\begin{array}{l}\text { Comprehensive dynamization of alternative food } \\
\text { networks in Orduña County }\end{array}$ \\
\hline \multirow[t]{3}{*}{ PrvC1 } & \multirow[t]{3}{*}{$\begin{array}{l}\text { Shepherd's School } \\
\text { (Catalunya) }\end{array}$} & $\begin{array}{l}\text { Specialized training itinerary design for new } \\
\text { entrants into livestock farming }\end{array}$ \\
\hline & & $\begin{array}{l}\text { Participatory research for local public } \\
\text { slaughterhouse reopens in Pallars-Sobirá County. }\end{array}$ \\
\hline & & $\begin{array}{l}\text { 'Espai test' program design- Training on organic } \\
\text { livestock farming and new entrants } \\
\text { accompaniment }\end{array}$ \\
\hline PrvC2 & $\begin{array}{l}\text { 'Arran de Terra' } \\
\text { Association-Collserola } \\
\text { Natural Park (Catalunya) }\end{array}$ & $\begin{array}{l}\text { Participatory process for agroecological transition } \\
\text { in Collserola Natural Park }\end{array}$ \\
\hline PrvC3 & $\begin{array}{l}\text { Association of } 9 \text { Town } \\
\text { Councils and five civic } \\
\text { organizations (Euskadi) }\end{array}$ & $\begin{array}{l}\text { Set up of County Food Council in Aiaraldea } \\
\text { County }\end{array}$ \\
\hline PrvC3 & $\begin{array}{l}\text { Producers' Group } \\
\text { (Catalunya) }\end{array}$ & Participatory design of short agri-food chains \\
\hline \multirow[t]{2}{*}{ PrvC4 } & \multirow{2}{*}{$\begin{array}{l}\text { Livestock Farmers } \\
\text { Association L'Esquella } \\
\text { (Pais Valenciá) }\end{array}$} & $\begin{array}{l}\text { Agroecological farming methods' advice for } \\
\text { livestock farmers }\end{array}$ \\
\hline & & $\begin{array}{l}\text { Participatory design of mobile slaughterhouse for } \\
\text { organic pastoralist farmers }\end{array}$ \\
\hline $\begin{array}{l}\text { PrvM } \\
1\end{array}$ & $\begin{array}{l}\text { Private consultancy for } \\
\text { Cardedeu Town Council } \\
\text { (Catalunya) }\end{array}$ & $\begin{array}{l}\text { Dynamization of organic food networks (i.e., } \\
\text { farmers' market) in Cardedeu municipality }\end{array}$ \\
\hline $\begin{array}{l}\text { PrvM } \\
2\end{array}$ & $\begin{array}{l}\text { Private consultancy } \\
\text { (Catalunya) }\end{array}$ & $\begin{array}{l}\text { Participatory process for agri-food sector in Canet } \\
\text { de Mar municipality, from an agroecological }\end{array}$ \\
\hline
\end{tabular}




\begin{tabular}{|l|l|l|}
\hline & & approach \\
\hline PrvM & Private consultancy for & Participatory design of training program for \\
3 & Vallehermoso City Council & agroecological self-employment in Vallehermoso \\
and Garajonay National & municipality \\
\cline { 3 - 3 } & $\begin{array}{l}\text { Park Consortium (Canary } \\
\text { Islands) }\end{array}$ & $\begin{array}{l}\text { Participatory planning for fire prevention in } \\
\text { Garajonay National Park }\end{array}$ \\
\hline PrvM & 'La Troje' Association- & Participatory dynamization of landrace bean \\
4 & $\begin{array}{l}\text { Madrid Seeds Network } \\
\text { growers Association of Madrid's Sierra Norte }\end{array}$ & Madrid)
\end{tabular}

